\title{
全習法と分習法が左右逆転プリズム眼鏡装着した 歩行練習に与える学習効果の比較
}

\author{
Comparison of Gait between Whole-task and Part-task Practices while Wearing \\ Prism Glasses Causing Right-left Reversal of the Visual Field
}

越後 あゆみ ${ }^{1,2}$ 岩月 宏泰 ${ }^{2}$

AYUMI ECHIGO, RPT, MS ${ }^{1,2)}$, HIROYASU IWATSUKI, RPT, MBA, LLM, PhD ${ }^{2)}$

${ }^{1)}$ Tohoku Medical College: 3-638 Naeshirozawa, Gonohe-machi, Sannohe-gun, Aomori 039-1522, Japan TEL +81 178-61-0606 E-mail:ayumi-nakamura@rinken.ac.jp

${ }^{2)}$ Graduate School of Health Sciences, Graduate School of Aomori University of Health and Walfare

Rigakuryoho Kagaku 32(2): 267-272, 2017. Submitted Sep. 8, 2016. Accepted Nov. 24, 2016.

\begin{abstract}
Purpose] The purpose of this study was to analyze the learning effects of whole-task and part-task practices of walking with prism glasses. [Subjects and Methods] Twenty healthy persons (12 men and 8 women) participated in this study. They wore prism glasses causing right-left reversal of the visual field, and were asked to walk $5 \mathrm{~m}$, turn around, and walk back $5 \mathrm{~m}$ to the starting point at their preferred speed. They performed the walking task once under each of three conditions: one whole-task and two part-task practices. Walk time, number of course corrections, steps, gait cycle time, muscle activities of the right tibialis anterior and gastrocnemius muscle, and trunk and ankle angles were measured during the walking tasks. [Results] The indices of walking performance and muscles activities in the lower limb showed no significant differences among the whole-task and part-task practices. However, walking time after whole-task practice was shorter than that of the part-tasks. [Conclusion] No significant changes in walking performance with prism glasses was observed after both whole-task and part-task practices.
\end{abstract}

Key words: whole-task practice, part-task practice, walking

要旨：〔目的〕健常青年を対象に左右逆転プリズム眼鏡を装着させた歩行を課題とし，全習法と分習法で練習を行っ た場合の学習効果を運動学的に解析することを目的とした。〔対象と方法〕下肢に整形外科的既往のない健常青年 20


件後の計 5 回実施した. 歩行時は, 所要時間, 修正回数, 歩数, 1 歩行周期時間, 下腿笳活動, 歩行時体幹動摇, 足 関節角度を測定した。練習条件は全習法と分習法の 2 種類を行った。〔結果〕全練習条件間で所要時間, 修正回数に 有意な差は認められなかった。練習中の変化として全習法のみ所要時間の短縮が認められた。〔結語〕練習法の違い による動作上達度に違いはないが, 課題習熟過程には差が生ずることが示唆された.

キーワード：全習法, 分習法, 歩行動作

1) 東北メデイカル学院：青森県三戸郡五戸町字苗代沢3 番地 638 ( ₹ 039-1522) TEL 0178-61-0606

2) 公立大学法人 青森県立保健大学大学院 健康科学研究科

受付日 2016 年 9 月 8 日 受理日 2016 年 11 月 24 日 


\section{I. はじめに}

理学療法の中で, 対象者に動作を獲得させる練習方法 として, 全習法と分習法がよく用いられる。全習法は課 題を始めから終わりまで行い，それを反復する方法であ る.この方法は, 運動の遂行時間が短く, 先行する動き が次の動きに影響するような課題動作の場合に有効とさ れている。 これに対し, 分習法は課題をいくつかの部分 に分けて練習する方法であり, 運動の遂行時間の長い課 題や各部分が独立して成り立っているような課題動作に は有効とされている ${ }^{1-3)}$.

しかし，これら二つの練習方法にはその効果に対する 定説はなく, 課題とする動作の違いによって効果は異な る.これまでの研究 4-6) では, 複雑な課題動作での学習 効果の比較は行われているが, 連続性のある歩行動作や 立ち上がり動作のような課題動作に対し, 全習法と分習 法の効果を比較したものはない. 歩行動作の練習では, 基本的な運動機能を部分練習により向上させることは必 要だが, 実用的な機能を獲得させるためにはできるだけ 早く, 運動機能レベルに応じた全体練習に移行したほう が良いと言われている7). そのため, 全習法での練習も しくは歩行動作に近い状態での分習法が望ましいと考え る.しかし, 歩行動作獲得について全習法と分習法を比 較した報告はない.

運動の習得について，プリズム眼鏡を用いた上肢運動 による報告は多い，それは，プリズム眼鏡を装着するこ とにより視覚情報を一時的に擋乱させた状態で運動の習 得過程を検討している。 それらの報告では, 上肢運動課 題は練習をすることで動作の上達が可能であったと述べ られている ${ }^{8,9)}$. プリズム眼鏡装着した立位や歩行動作 に関する研究では, プリズム眼鏡を装着することで歩行 動作は小刻みとなり直進することが困難となることが報 告されている ${ }^{10-16)}$ が, 練習による動作の習得を報告し たものはない.
本研究では，健常青年を対象に左右逆転プリズム眼鏡 を装着した歩行を主課題とし, 全習法と分習法で練習を 行った場合の歩行動作の上達効果を運動学的要因の比較 から明らかにすることと, それらの要因がどの程度上達 に関連しあっているのかを検討することを目的とした。

\section{II. 対象と方法}

1. 対象

対象は下肢に外傷がなく平衡機能障害を有さない健常 青年 20 名（年齢： $20.4 \pm 0.5$ 歳, 身長 : $166.3 \pm 8.4 \mathrm{~cm}$, 体重: $59.3 \pm 16.1 \mathrm{~kg}$ ) で, 男性 12 名, 女性 8 名であっ た。 な扮, 本研究は青森県立保健大学研究倫理審査委員 会の承認を得て行われて扮り（承認番号 1507), 研究に 参加する対象者には研究内容に関する説明を十分に行い, 同意書を取得した。

\section{2. 方法}

測定は全て屋内で実施し, 照度 $2001 \mathrm{x}$ となるように 調整した，また，動作時視界に入り手掛かりとなるもの がないよう, 壁と同一のアイボリー色の布で覆った。

課題は $5 \mathrm{~m}$ 先で開始点まで戻ってくる屋内平地歩行 とし, これを歩行テストとし, 歩行テストには左右逆転 プリズム眼鏡 (竹井機器工業社製, 水平 $24^{\circ}$, 垂直 $50^{\circ}$ ：以下，プリズム）を使用した。歩行テストはプリ ズム非装着時と装着直後, 3 条件の練習後に各 1 回ずつ 計 5 回実施した。練習条件は，床面のテープを目印に歩 行路を全て歩く練習（全習法）, 左右の目印に向かい 1 歩踏み出す練習 (分習法 1), 目印に合わせて 4 歩進む 練習（分習法2）の3つとし（図 1), 全条件とも5 回 ずつ試行した，各練習実施時の教示内容として，全習法 では目印の線から外れないようにテープに沿って歩くよ う指示した．分習法 1 では前方の枠に足が入るように踏 み出すことを指示した，分習法 2 では目印の枠から足が



$\mathrm{a}$ ：全習法
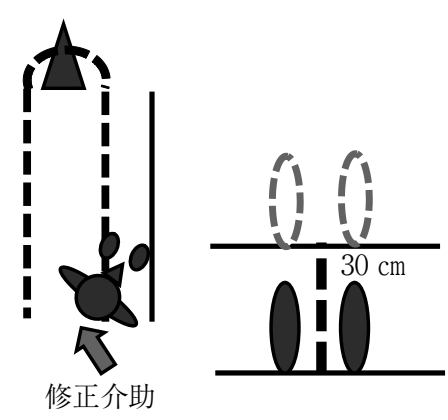

$\mathrm{b}$ ：分習法 1
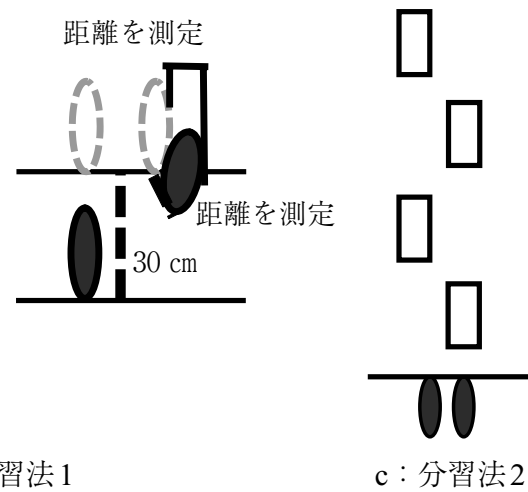

図1練習条件

$\mathrm{a}$ ：歩行テストと同様のコースを目印の線に沿って歩く練習, $\mathrm{b} ： 30 \mathrm{~cm}$ 前方の枠に向かって逸脱するこ となく踏み出す練習, $\mathrm{c}$ ：四つの枠から逸脱することなく4歩前進する練習. 
はみ出ることがないよう４歩進むように指示した，全習 法は歩行所要時間を, 分習法 1 は左右の目印から踵の前 後逸脱距離と足部の内外側逸脱距離を, 分習法 2 は目印 から逸脱した回数と所要時間を測定した。なお，実施回 数によるプリズム適応の影響を除去するため各練習間に はプリズムを外した状態で 10 分の休䡯を取った。また, 歩行テスト直後にプリズム装着状態で線分二等分テス卜 とポインティングテストを実施した。また，対象ごとに 実施する練習条件の順番を変更しランダムに実施した。

歩行テストが全て終了した時点で, プリズム装着感や 歩行練習についての質問紙調查を実施した。質問は(1)プ リズムの装着に関して, (2)各条件で練習した後の歩行に 関して, (3)各練習条件についての3つの大項目から構成 されていた，それぞれの質問に対し感じた思いを，「5： とても思う，4：思う，3：どちらでもない，2：思わな い, 1 : 全く思わない」の 5 件法で最も当てはまるもの を選び，丸で囲んでもらった。

測定項目は歩行テスト時に表面筋電図, 1 歩行周期時 間, 加速度計にて前後·左右 ·上下の摇れ, 足関節角度, 歩行所要時間，修正回数，歩数を測定した，表面筋電図， 1 歩行周期時間, 加速度, 足関節角度はすべて多チャン ネルテレメーターシステム (WEB-1000, 日本光電社製) を使用した。表面筋電図はサンプリング周波数 $1,000 \mathrm{~Hz}$ とし, 単極誘導により筋電波形を導出した。ワイヤレス 電極を右側の前脛骨筋（以下, TA）と腓腹筋外側頭（以 下, GM）に粘着した。筋電図信号は筋電用増幅器で $\mathrm{A} /$ $\mathrm{D}$ 変換し, 筋電解析用パーソナルコンピューターに取り 込んだ. 30 から $500 \mathrm{~Hz}$ のバンドパスフィルタをかけ全 波整流を行った後, 二乗平均平方根 (Root Mean Square：以下, RMS）を算出した. RMS は 1 歩行周期 ごとに計測し平均值を算出した，それを最大随意収縮 (Maximal Voluntary Contraction：以下, MVC) で除した 值を比 MVC, プリズム非装着時 RMS で除した值を比 EMG とした。 右足底踵部に加圧センサー（日本光電社 製：以下，フットスイッチ）を貼付し右踵接地からの 1 歩行周期時間を矩形波として導出した。 三軸加速度計ワ イヤレスセンサーを額部に貼付し, 頭部の上下・左右・ 前後の摇れを導出した。 また, 全歩行周期に扔ける各成 分の摇れの最大最小のピーク值の差 $(\mathrm{Hz})$ を求めた.

統計的解析は, プリズム装着により歩行に変化が起 こっているかを確認するため非装着時と装着時の各測定 項目を対応のある $\mathrm{t}$ 検定を用いて比較した。 また，プリ ズム装着時と各条件後, 各条件間での歩行の上達度を比 較するため測定項目に対し反復測定分散分析を行った。 練習中の上達度として, 全習法は所要時間, 分習法 1 は 踵の前後逸脱距離と足部の内外側逸脱距離, 分習法 2 は 逸脱回数と所要時間のそれぞれを練習回数間で比較する ため, 一元配置分散分析を行い効果が認められたものに 対して多重比較（Tukey 法）を実施した，さらに，測定
項目間の関係として Pearsonの積率相関係数を算出し た。な扮，有意確率 $5 \%$ 未満を差ありとみなした。

\section{III. 結 果}

プリズム非装着に比べ，プリズム装着直後の歩行テス トでは歩行所要時間, 修正回数は有意に増加し, GMの 筋活動は有意に低下し $(\mathrm{p}<0.01), \mathrm{TA}$ は低下傾向にあっ た. 一方, 足関節角度には変化が起こらなかった（表1）。 このことから，プリズム装着で歩行が変化したことが言 える，そこで，プリズム装着直後と各条件での練習後の 歩行所要時間と修正回数を比較した（表 2). 歩行所要 時間はプリズム装着直後に比べ全練習条件後で有意に短 縮し, 修正回数も有意に減少した $(\mathrm{p}<0.05)$. しかし, どちらも練習条件間での差は認められなかった。

各練習条件での練習中の変化を表 2 4 亿示す，全習 法では, 練習回数を重ねるごとに歩行所用時間が短縮し た. 1 回目と 4 回目, 1 回目と 5 回目の間以外には有意 な差が認められなかった（表 3 ). 分習法 1 では, 一歩 踏み出した時の踵の前後逸脱距離と足部の内外側への逸 脱距離を測定したが, 練習回数間で有意な差は認められ なかった（表 4). 分習法 2 では, 4 歩進む所要時間と, 足部の逸脱回数ともに練習回数の増加に伴い減少傾向に あるものの, 有意な差は認められなかった（表 5).

歩行テストと各条件での練習が全て終了した後でも， 実施回数の増加に伴う等分性の向上やポインティング時 間の短縮は認められなかった。

測定項目間の関連性を表 6,7 に示す。全習法では歩 行所要時間と修正回数 $(r=0.83), 1$ 歩行周期時間 $(r=$ $0.77)$, 歩数 $(r=0.83)$, 足関節角度 $(r=0.62)$ 間に, 修正回数と歩数 $(r=0.84)$, 足関節角度 $(r=0.63)$ 間に $(\mathrm{p}<0.01) ， 1$ 歩行周期時間 $(\mathrm{r}=0.51)$ 間に $(\mathrm{p}<0.05)$

表 1 プリズムを装着したことによる歩行の変化

\begin{tabular}{lcc}
\hline 測定項目 & プリズム非装着 & プリズム装着 \\
\hline 歩行所要時間 $(\mathrm{sec})$ & $9.1 \pm 1.9$ & $33.0 \pm 18.3^{* *}$ \\
修正回数 (回) & 0 & $6.0 \pm 4.1^{* *}$ \\
$\mathrm{TA}$ 比 MVC & $3.0 \pm 3.8$ & $1.5 \pm 1.5$ \\
$\mathrm{GM}$ 比 MVC & $4.5 \pm 6.7$ & $2.1 \pm 2.6^{* *}$ \\
$\mathrm{TA}$ 比 EMG & 1 & $0.8 \pm 0.3$ \\
$\mathrm{GM}$ 比 EMG & 1 & $0.6 \pm 0.2^{* *}$ \\
1 歩行周期時間 & $1.0 \pm 0.1$ & $1.4 \pm 0.3^{* *}$ \\
歩数 & $16.7 \pm 3.3$ & $45.7 \pm 16.1^{* *}$ \\
上下成分 & $1.1 \pm 0.3$ & $0.8 \pm 0.3^{* *}$ \\
左右成分 & $0.7 \pm 0.3$ & $0.6 \pm 0.2^{* *}$ \\
前後成分 & $1.0 \pm 0.3$ & $0.8 \pm 0.2^{* *}$ \\
足関節角度 & $25.4 \pm 12.2$ & $29.6 \pm 8.0$ \\
\hline
\end{tabular}

平均值 \pm 標準偏差. $\mathrm{TA}$ : 前脛骨筋, $\mathrm{GM}$ : 腓腹筋外側頭. $* *: \mathrm{p}<0.01$. 
表 2 各練習後の歩行テストに抢ける歩行所要時間と修正回数の変化

\begin{tabular}{lcccc}
\hline & プリズム & 全習法 & 分習法 1 & 分習法 2 \\
\hline 歩行所要時間 $(\mathrm{sec})$ & $33.4 \pm 17.8$ & $21.4 \pm 7.2^{*}$ & $23.6 \pm 10.9^{*}$ & $23.6 \pm 11.7^{*}$ \\
修正回数 $($ 回 $)$ & $5.9 \pm 4.0$ & $4.5 \pm 2.3^{*}$ & $4.6 \pm 3.3^{*}$ & $3.8 \pm 3.3^{*}$ \\
$\mathrm{TA}$ 比 MVC & $1.5 \pm 0.3$ & $2.0 \pm 0.5$ & $2.4 \pm 1.1$ & $2.6 \pm 0.8$ \\
$\mathrm{GM}$ 比 MVC & $2.1 \pm 0.6$ & $3.7 \pm 1.2$ & $4.4 \pm 2.1$ & $7.1 \pm 3.4$ \\
$\mathrm{TA}$ 比 EMG & $0.8 \pm 0.1$ & $1.1 \pm 0.2$ & $0.8 \pm 0.2$ & $1.0 \pm 0.2$ \\
GM 比 EMG & $0.7 \pm 0.2$ & $1.1 \pm 0.6$ & $0.8 \pm 0.2$ & $0.9 \pm 0.4$ \\
1 歩行周期時間 & $1.4 \pm 0.1$ & $1.2 \pm 0.0^{*}$ & $1.2 \pm 0.1$ & $1.3 \pm 0.0$ \\
歩数 & $45.7 \pm 3.7$ & $34.5 \pm 2.0^{*}$ & $35.3 \pm 2.5^{*}$ & $34.7 \pm 2.5^{*}$ \\
上下成分 & $0.8 \pm 0.1$ & $0.7 \pm 0.0$ & $0.8 \pm 0.1$ & $0.8 \pm 0.1$ \\
左右成分 & $0.6 \pm 0.0$ & $0.6 \pm 0.1$ & $0.6 \pm 0.5$ & $0.6 \pm 0.6$ \\
前後成分 & $0.8 \pm 0.1$ & $0.8 \pm 0.1$ & $0.8 \pm 0.1$ & $0.8 \pm 0.1$ \\
足関節角度 & $29.6 \pm 1.9$ & $31.6 \pm 2.5$ & $33.7 \pm 2.8$ & $33.9 \pm 3.3$ \\
\hline
\end{tabular}

平均值 \pm 標準偏差. 略称は表 1 と同様. $*: \mathrm{p}<0.05$ (vs プリズム), \# $: \mathrm{p}<0.05$ (vs 分習法 2$)$.

表 3 全習法での練習中における歩行所要時間の変化

\begin{tabular}{lccccc}
\hline & 1 回目 & 2 回目 & 3 回目 & 4 回目 & 5 回目 \\
\hline 歩行所要時間 $(\mathrm{sec})$ & $36.6 \pm 18.0$ & $29.0 \pm 10.5$ & $25.5 \pm 8.3$ & $24.8 \pm 8.2 *$ & $22.8 \pm 7.2^{*}$ \\
\hline 平均值 \pm 標準偏差. $*: \mathrm{p}<0.05$ (vs 1 回目).
\end{tabular}

表 4 分習法 1 での練習中における足部逸脱距離位置の変化

\begin{tabular}{lccccc}
\hline & 1 回目 & 2 回目 & 3 回目 & 4 回目 & 5 回目 \\
\hline 前後 $(\mathrm{cm})$ & & & & & \\
$\quad$ 右 & $6.1 \pm 9.7$ & $6.1 \pm 16.6$ & $4.6 \pm 7.8$ & $3.4 \pm 6.3$ & $2.7 \pm 4.5$ \\
$\quad$ 左 & $6.3 \pm 7.1$ & $4.5 \pm 6.9$ & $4.1 \pm 4.7$ & $3.4 \pm 4.5$ & $1.7 \pm 3.6$ \\
内外側 $(\mathrm{cm})$ & & & & & \\
右 & $5.1 \pm 9.7$ & $10.3 \pm 11.1$ & $12.4 \pm 13.8$ & $9.4 \pm 13.6$ & $6.3 \pm 9.2$ \\
左 & $10.1 \pm 17.4$ & $8.1 \pm 8.2$ & $6.4 \pm 6.0$ & $9.5 \pm 9.0$ & $8.9 \pm 9.1$ \\
\hline
\end{tabular}

平均值 \pm 標準偏差.

表 5 分習法 2 での練習中における歩行所要時間と逸脱回数の変化

\begin{tabular}{lcrrrr}
\hline & 1 回目 & 2 回目 & \multicolumn{1}{c}{3 回目 } & \multicolumn{1}{c}{4 回目 } & \multicolumn{1}{c}{5 回目 } \\
\hline 歩行所要時間 $(\mathrm{sec})$ & $14.8 \pm 11.1$ & $11.5 \pm 6.6$ & $11.7 \pm 7.3$ & $10.8 \pm 7.4$ & $10.1 \pm 7.1$ \\
逸脱回数 $($ 回 $)$ & $3.5 \pm 0.7$ & $3.4 \pm 0.8$ & $3.1 \pm 0.8$ & $2.9 \pm 1.1$ & $2.7 \pm 1.1$ \\
\hline
\end{tabular}

平均値 \pm 標準偏差.

有意な正の相関が認められた。分習法 1 は，歩行所要時 間と修正回数 $(r=0.83), 1$ 歩行周期時間 $(r=0.87)$, 歩数 $(\mathrm{r}=0.88)$ 間に $(\mathrm{p}<0.01)$ ，角度 $(\mathrm{r}=0.52)$ 間に $(\mathrm{p}<0.05)$ 有意な正の相関が認められた。 また, TA 比 MVC $(r=-0.72)$, TA 比 EMG $(r=-0.72)$ で有意な 負の相関が認められた $(\mathrm{p}<0.05)$. 修正回数と歩数 $(\mathrm{r}=0.84)$ 間に $(\mathrm{p}<0.01), 1$ 歩行周期時間 $(\mathrm{r}=0.51)$ 間に $(\mathrm{p}<0.05)$ それぞれ有意な正の相関を, TA 比 MVC $(r=-0.66)$, TA 比 EMG $(r=-0.66)$ で有意な
負の相関を認めた $(\mathrm{p}<0.05)$. 分習法 2 は, 歩行所要時 間と修正回数 $(r=0.81), 1$ 歩行周期時間 $(r=0.64)$, 歩数 $(r=0.88)$ 間に $(\mathrm{p}<0.01)$, 修正回数と歩数 $(\mathrm{r}=$ $0.81)(\mathrm{p}<0.01)$, 足関節角度 $(\mathrm{r}=0.53)$ 間に $(\mathrm{p}<0.05)$ それぞれ有意な正の相関を認めた。

アンケート結果では, プリズムの装着感, 各練習条件 後の歩行や練習条件のやりやすさで条件間の違いは認め られなかった。 
表 63 条件における歩行所要時間と各測定項目の相関 係数 (r)

\begin{tabular}{lccc}
\hline & 全習 & 分習 1 & 分習 2 \\
\hline 修正回数 & $0.83^{* *}$ & $0.83^{* *}$ & $0.81^{* *}$ \\
TA 比 MVC & -0.51 & $-0.72^{*}$ & -0.27 \\
TA 比 EMG & -0.55 & $-0.72^{*}$ & -0.18 \\
GM 比 MVC & -0.39 & -0.06 & 0.12 \\
GM 比 EMG & -0.54 & -0.16 & -0.22 \\
1 歩行周期時間 & $0.77 * *$ & $0.87 * *$ & $0.64 * *$ \\
歩数 & $0.83^{* *}$ & $0.88^{* *}$ & $0.88^{* *}$ \\
上下成分 & 0.07 & -0.29 & -0.12 \\
左右成分 & 0.00 & 0.37 & 0.18 \\
左右成分 & -0.07 & 0.1 & -0.15 \\
足関節角度 & $0.62 * *$ & $0.52 *$ & 0.46 \\
\hline
\end{tabular}

略称は表 1 と同様. * : p $<0.05, * *: \mathrm{p}<0.01$.

\section{IV. 考 察}

本研究では,プリズム装着により視空間認知を攪乱し た歩行を主課題とし, 全習法, 分習法 $1 \cdot 2$ の 3 条件で の上達度を歩行所要時間と修正回数から比較検討した。 本研究の結果, 2つの練習方法において最終的な歩行所 要時間や修正回数に差を認めなかった。このことから練 習条件による練習効果には違いがないことが示唆された。

一般的に, 分習法は遂行時間の長い課題動作や各部分 が独立してなり立っているような課題動作には有効であ るが，遂行時間が短く先行する動きが次の動きに影響す るような課題動作では全習法の方が良いと言われてい る.そのため, 我々は歩行テストと同様の歩行路で練習 する全習法が有効と考えていたが, 分習法においても歩 行動作は上達していた。分習法は自動化できる部分を重 点的に練習することに適している17)とされ，苦手な部 分を集中的に練習できることがメリットである。今回, 対象のほとんどがプリズム装着時に小刻み様歩行となり 直進不能となった，Kuoら 18) は，歩行時の側方安定性 は能動的なコントロールが必要であるが, 前後方向は比 較的受動的に行われると述べている. 分習法の練習条件 では目印に向かい一歩を振り出すため, 正確な前後・内 外側へのコントロールが必要とされる。 しかし, 内外側 の逸脱距離は練習回数が増えても減少することがなかっ たのに対し，前後方向の逸脱距離は減少傾向にあった。 このことから, 前後方向のコントロールは視覚の影響を 受けにくく，自動化できる部分であり前後方向振り出し の上達が歩行の上達につながったと考える.

また，全練習条件で上達に関連する項目が共通してい ることが挙げられる. 本研究では, 歩行動作の上達の指 標として歩行所要時間や修正回数を記録した. 歩行所要 時間では修正回数，1歩行周期時間，歩数の間に関連が あり, 修正回数では歩数と関連していた。 これらの項目
表 7 修正回数と各測定項目間の相関係数

\begin{tabular}{lccc}
\hline & 全習 & 分習 1 & 分習 2 \\
\hline TA 比 MVC & -0.32 & $-0.66^{*}$ & -0.18 \\
TA 比 EMG & -0.05 & $-0.66^{*}$ & -0.19 \\
GM 比 MVC & -0.35 & -0.13 & 0.26 \\
GM 比 EMG & -0.15 & -0.27 & -0.13 \\
1 歩行周期時間 & $0.51^{*}$ & $0.51^{*}$ & 0.29 \\
歩数 & $0.84^{* *}$ & $0.84^{* *}$ & $0.81^{* *}$ \\
上下成分 & 0.26 & -0.3 & -0.06 \\
左右成分 & 0.33 & 0.45 & 0.25 \\
左右成分 & -0.01 & 0.15 & -0.03 \\
足関節角度 & $0.63^{* *}$ & 0.29 & $0.53^{*}$ \\
\hline
\end{tabular}

略称は表 1 と同様. * : p $<0.05, * *: \mathrm{p}<0.01$.

は全条件で共通しており，高い正の相関を示した。この ことから, 歩行動作の上達には共通した要因が関連して いるため, 練習条件が異なっても上達度に差が生じな かったことが考えられた.

さらに，全習法と分習法の練習効果に差は生じなかっ たが, 練習の上達過程には違いを認めた。全習法では練 習の過程で変化が起こり, 練習初期と後半で所要時間が 短縮した。 しかし, 分習法 1 では練習初期と後半で変化 を認めなかった。このことから，全習法は即時的な効果 が現れやすいことが考えられた．Sattelmayerら19)は全 習法と分習法の効果について, 全習法は即時的な効果が 出現しやすく, 分習法では学習の保持において効果的で はないかと述べている，また，Morton ら 20) は歩行の協 調性を乱した結果，ストライド長やステップ時間は外乱 後すぐに一定に戻ることができるが，ステップ長や両脚 支持時間はすぐには適応せず学習期中盤になって安定し たと述べている。このことからも，ステップ長を繰り返 し練習した分習法 1 では練習中に歩行全体に変化が起こ りにくかったと考えられた。

なお, 練習方法の違いにより動作の上達度に違いは認 めなかったが練習の過程に変化を認めた。 プリズム装着 直後は, 左右反転した視覚情報をフィードバックとして 用いていたことが予測され全対象において歩行所要時間 の延長と修正回数の増加が起こったと考える，だが，プ リズム適応は起こらなくとも練習によって歩行所要時間 は有意に短縮した，このことから，視覚以外の体性感覚 情報に寄与し動作を上達させていたことが考えられた。 しかし, 今回の結果からは優位に使用していた感覚情報 は明らかではない. 今後は, 動作上達時の知覚情報の選 択ついて明らかにすることが課題となる。

左右逆転プリズム眼鏡を用い動作の習熟度を比較した 研究で, 練習法を変え比較した研究はない.しかし, Martinら 9) は的にボールを当てるという課題で練習回 
数を 30 回に設定したところ上達したと報告している. 本研究では, セット数は 5 回と設定したが全試行回数と して練習条件間で同等の影響を及ぼしていたかは明らか ではない，そのため，練習条件が異なる場合の練習回数 に関して検討が必要である，また，上達の指標として用 いた測定項目に関しても検討が必要である。歩行テスト に扔いて所要時間や修正回数を用い比較したが，その他 の項目で条件間の違いが認められた項目は 1 歩行周期時 間のみであった。今後は 1 歩行周期時間の上達に関連す る項目を選択し，関連する活動筋の計測を含め検討する 必要がある。

本研究は，左右逆転プリズム眼鏡を装着した歩行を主 課題とし，全習法と分習法で練習を行った場合の動作に 対する学習効果を運動学的に解析, 比較した。 その結果, プリズム装着直後に比べ, 全練習条件で歩行所要時間は 有意に短縮したが，練習条件間に差を認めなかった。こ のことから, 練習条件の違いで課題動作の上達に差はな いことが示唆された。それは課題動作の上達に関連する 要因が全条件で共通していたことが考えられる。しかし， 練習の過程には違いがあることが考えられた。これらの ことから，臨床で歩行動作に障害のある患者に対し練習 法を選択する際は, 歩行動作の上達に関連する要因や上 達の過程に配慮する必要がある。また, 全習法では即時 的に練習効果が提示しやすいことが示唆された。

\section{引用文献}

1) 石川 朗, 種村留美：15レクチャーシリーズ運動療法学 作業療法学テキスト・運動学. 中山書店, 東京, 2012, pp136-137.

2) 中村隆一, 斉藤 宏, 長崎 浩·他: 基礎運動学, 第6版補訂. 医歯薬出版, 東京, 2003, p498.

3) Fontana FE, Mazzardo O, Furtado O Jr, et al.: Whole and part practice: A meta-analysis. Percept Mot Skills, 2009, 109: 517-530.

4) 米田浩久, 鈴木俊明 : 全習法と異なる二種の分習法での運 動学習効果の検討. 理学療法科学, 2014, 29: 809-813.
5) So JC, Proctor RW, Dunston PS, et al.: Better retention of skill operating a simulated hydraulic excavator after part-task than after whole-task training. Hum Factors, 2013, 55: 449-460.

6) 大石杉乃，平林千佳里，大原宏子：血圧測定技術の教授方 法に関する検討一分習法と全習法を比較して一，看護展望， 1994, 19: 1150-1158.

7) 大橋ゆかり：運動学習 $\mathrm{ABC}$. 文光堂, 東京, 2004, p102.

8) Sugita Y: Global plasticity in adult visual cortex following reversal of visual input. Nature, 1996, 380: 523-526.

9) Martin TA, Keating JG, Goodkin HP, et al.: Throwing while looking through prisms. II. Specificity and storage of multiple gaze-throw calibrations. Brain, 1996, 119: 1199-1211.

10) Ewert PH: A study of the effect of inverted retinal stimulation upon spatially coordinated behavior. Genet Psychol Monogr, 1930, 7: 177-363.

11) Peterson J, Peterson JK: Dose practice with inverting lenses make vision normal? Psychol Monogr, 1938, 50: 12-37.

12) 平松 隆：直立姿勢の視性制御の研究一逆転プリズムを用 いて一. Equilib Res, 1991, 50: 263-274.

13) Gonshor A, Jones GM: Postural adaptation to prolonged optical reversal of vision in man. Brain Res, 1980, 192: 239-248.

14) Yoshimura H, Ohkura M: Effects of up-down reversed vision and left-right reversed vision on walking tasks. Psychologia, 1983, 26: 159-166.

15) 斎藤 晶, 高橋正紘, 岡田行弘・他 : 視野逆転プリズム による動摇病の研究 (第 1 報)。 日本耳鼻咽喉科学会会報, 1991, 94: 198-202.

16) 平松 隆, 高木恭也, 森 芳郎・他: 歩行における視覚情 報の役割について。. Equilib Res, 1991, 50: 322-328.

17) Schneider W: Training high-performance skills: Fallacies and guidelines. Hum Factors, 1985, 27: 285-300.

18) Kuo AD, Donelan JM: Dynamic principles of gait and their clinical implications. Phys Ther, 2010, 90: 157-174.

19) Sattelmayer M, Elsig S, Hilfiker R, et al.: A systematic review and meta-analysis of selected motor learning principles in physiotherapy and medical education. BMC Med Educ, 2016, 16: 15 .

20) Morton SM, Bastian AJ: Cerebellar contributions to locomotor adaptations during splitbelt treadmill walking. J Neurosci, 2006, 26: 9107-9116. 